\title{
Çoruh Nehri ve Yusufeli Barajı: Toplumsal, Ekonomik ve Çevresel Etkileri Bakımından Bir Baraj İncelemesi
}

\author{
Yusuf KÜÇÜKBAŞOL ${ }^{1}$
}

Öz: Çoruh Nehri üzerinde Muratlı Barajı ve HES 1999 yılında, Borçka Barajı ve HES 2007 yılında Deriner Barajı ve HES 2013 yılında yapımı tamamlanarak işletmeye alınmıştır. Barajların tamamı işletmeye alındığında yıllık 8322 GWh elektrik üretimi ile ülkemiz toplam enerji üretiminin yaklaşık \% 8'ini, hidroelektrik santrallerinden elde edilen toplam enerjinin ise yaklaşı1k \% 34'ünü oluşturacaktır. Fakat projelerin yapım sürecinde bazı maliyetler göz ardı edilmekte ve düşük maliyet gösterilmektedir. Dünya Bankası (DB) ve Uluslararası Para Fonu (IMF) gibi uluslar arası finans kuruluşları, dünyanın pek çok bölgesinde özelleştirmelere mali ve teknik destek sağlayarak bu konuda yapılan çalışmaları teşvik etmektedir. Özel sektör tarafından yapılan yatırımların devlete ek maliyet getirmemesi için, devlet tarafından gerekli tedbirler alınmaktadır. Gelişmiş ülke olabilmek için hidroelektrik enerji potansiyellerimiz üretime sokulmaktadır. Çalışmamızda, ülkemizin elektrik ihtiyacını karşılamak ve enerji için diğer ülkelere bağımlılı̆̆ı azaltmak için ülkemizin aşırı yağış alan Karadeniz bölgesinin enerji üretimine sokulması gerektiği, heyelan ve sel riski taşıyan bölgelerde yaşayan insanların daha güvenli bölgelere taşımanın önemli olduğu, baraj ve santrallere karşı halkın tepki göstermesinin dış güçler tarafından yönlendirildiği gözler önüne serilmeye çalışılacaktır. 
Anahtar kelimeler: Çoruh Vadisi, Çoruh Nehri, Yusufeli Barajı, Baraj Politikaları, Yamaç HES,

\section{Giriş}

Türkiye'nin kuzeydoğusunda güneybatı-kuzeydoğu istikametinde uzanan Çoruh Nehri, 390 km.'lik uzunluğu ile Erzurum Dağlarından doğup, Kaçkarlar’ı aşarak Doğu Karadeniz'den Gürcistan'a ulaşmakta, oradan da $20 \mathrm{~km}$. akıp Karadeniz'e dökülmektedir. Çoruh Nehri dünyanın hızlı akan on nehrinden birisi olup toplam 350 km.'yi aşkın kulvarı ile en uzun rafting nehirlerinden birisidir.

Tarihi 1969'larda başlayan, 1982 yılında master planı tamamlanan ve günümüze kadar devam eden "Çoruh Nehri Hidroelektrik Gelişme Planı” çerçevesinde Çoruh Nehri ana kolu üzerinde 10 adet barajlı Hidroelektrik Santral (HES), yan kollar üzerinde 5 adedi barajlı, 17 adedi regülatörlü olmak üzere toplam 32 HES yapılması planlanmıştır. Ana kol üzerinde yapilacak olan toplam on adet barajdan bir tanesi de $\mathrm{Yu}$ sufeli Barajı'dır. Bu barajlardan Muratlı Barajı akış aşağısında olan en son baraj olup 1999 yılında inşaatına başlanılmış olup 2005 yılında işletmeye alınmıştır. Muratlı Barajının akış yukarısında bulunan Borçka Barajı 2007 yılında Deriner Barajı ise 2013 yılında işletmeye alınmıştır. Yusufeli Barajı̉nın inşaatına 2012 yılında başlanmıştır. Diğer barajlar ise planlama aşamasındadırlar.

\section{Su Kaynaklarının Piyasalaştırılması ve Barajların Rolü}

1945 ile 1970 yılları arasında devletin piyasaya müdahale ederek talep yaratmaya yönelik Keynesyen politikalar güdülmekteydi. Ulusal ekonomilerde düzenlemeci ve müdahaleci politikalar sürdürülürken uluslar arası piyasalarda ise uluslararası ekonomik ilişkileri düzenleme çabaları artarak devam etmiştir. 1970'li yılların sonlarına değin iktisadi kalkınmanın temel lokomotifi, sanayileşmiş ülkelerde toplam talebin genişletilmesi, sanayileşmemiş ülkelerdeyse ithal ikameci stratejilerdi (Yıkılmaz, 2003:50). 
1973 petrol krizi ile birlikte enflasyonda küresel ölçekte bir artış olmuş, 1974 yılının sonlarında ise kriz gelişmiş ülkeleri de etkisi altına almıştır. Bu krizde kâr oranlarının düşüşü ile birlikte aşırı bir birikim süreci de yaşanmış ve kapitalizmin bu aşırı birikimi üretken sermaye olarak değerlendirebilecekleri yeni alanlara ihtiyaç doğmuştur. Bu alanların başında bugüne kadar kamu hizmeti olarak tanımlanmış eğitim, sağlık, su hizmetleri, posta hizmetleri ve ulaşım gibi alanlar bulunmaktadır (Yılmaz, 2008:2). Böylelikle kamunun tekelinde bulunan hizmetler özelleştirme, kamu-özel ortaklığ1 vb. yollarla sosyal devletin s1nırları daraltılmış ve yeniden çizilmiştir. 1970 krizi ile birlikte üretim yapısında değişikliğe gidilmiş ve sermayenin önündeki engellerin kaldırılması, özelleştirme, sosyal devletin sınırlandırılması, işgücünün esnekleştirilmesi ve sendikaların güçlerinin azaltılması gibi düzenlemeler yeni dönemin temel taşlarını oluşturmuştur. Böylece küreselleşme süreci hızlanmıştır.

1980'li yılların ortalarında, enerji yatırımlarının özel kesime açılması kararlaştırılmış ve elektrik sektöründe özel kesim yatırım ve faaliyetlerini geliştirecek şekilde sektörün yeniden yapılandırılması öngörülmüştür. Ancak, bunun gerektirdiği düzenlemeler zamanında yapılmamış, özel kesimden beklenen yatırımlar ve katkılar alınamamıştır. Yatırımlarım artık özel kesim tarafından yapılması öngörüldügünden kamu yatırımlarında da yetersiz kalınmıştır. Bu arada, özel kesimi sektöre çekmek üzere "aşırı yüksek tarifelerle elektrik alım-ödeme garantileri, yakıt temin garantisi, hazine garantisi, uluslar arası tahkim gibi aşırı güvenceler verilmiştir (Ege, 2004:30). Bu gelişmeler rekabete açık bir piyasa oluşturulması amacı ile ters düşmüştür. Bu gelişmeler birincil enerji kaynaklarının temini ve tüketimi açılarından ekonomik bakımdan etkin olmayan sonuçlar doğurmuştur.

Başta DB ve IMF gibi uluslararası kuruşlular, gelişmekte olan ülkelere su hizmetlerinin uluslararası şirketlere açılması konusunda sürekli baskı yapmaktadırlar. Verimlik ve etkinlik gibi sloganlar ileri sürülerek su dağıtım sistemi özelleştirme yoluyla sermaye gruplarına devredilmek istenmektedir. Sermaye gruplarının su sanayine her geçen gün 
daha çok ilgi göstermesi, bu alanın parasal değerinin büyüklüğünden kaynaklanmaktadır. Dünya genelinde suların sadece \% 5'inin özelleştirilmiş olması, su piyasasının karının petrol piyasası karının \% 40’na ulaşmış olması, sermayenin neden bu alana ilgi gösterdiğini açıklamaktadır (Kartal, 2006:478-484).

Ancak özelleştirme konusunda pek çok başarısızlık olmasına rağmen DB ve IMF özelleştirmeyi gündeme getirmekten vazgeçmemektedir. Uluslar arası finans kuruluşları, dünyanın pek çok bölgesinde özelleştirmelere mali ve teknik destek sağlayarak bu konuda yapılan çalışmaları teşvik etmektedir. Latin Amerika'daki gibi borç içerisinde olan devletlerin gereksinim duyduğu krediler, su hizmetleri gibi kimi kamu hizmetlerinin özelleştirilmesine bağlanabilmektedir (Akdoğan, A. Argun, 2006:179-224).

Hem enerji üretimi hem de su taşkınlarının kontrol altına alınabilmesi amacıyla baraj inşa etme ihtiyacı ilk olarak gelişmiş ülkelerde ortaya çıkmıştır. Uygun iklim koşulları olmasına rağmen barajlara bu ülkelerde daima ihtiyaç duyulmuştur; ancak gelişmiş devletlerde hidrolik enerji üretimi, gelişmiş sanayilerinin su ihtiyacını karşılamak, sağlıklı ve güvenilir içme suyu temini ve taşkınlardan korunma ihtiyacı ön plana çıkmıştır. Belirtilen amaçlarla sayısız baraj tesisi edilmiştir. Barajlarda depolanan ve yeraltından çıkarılan dünyadaki kullanılabilir suyun $\%$ 10 'u evsel kullanımda, \% 20' si sanayide ve \% 70'i tarımda kullanılmaktadır. Tabii ki sanayide kullanım oranı gelişmiş ülkelerde artmakta, tarımda kullanım oranı ise daha çok ilkel tarım uygulayan üçüncü dünya ülkelerinde artmaktadır. Dünyadaki barajların üçte biri gelişmiş kuzey ülkelerinde bulunmaktadır. Fransa, İtalya ve İspanya gibi Avrupa ülkeleri ile $\mathrm{ABD}$ devletleri barajlar sayesinde sulamaya da büyük önem vermiştir. ABD’nin batı ve güney kesimlerinde 21,4 milyon hektar sulu tarım yapılmaktadır. Bu çalışmalar 1990’lı yıllarda büyük oranda tamamlanmıştır. Gelişmiş ülkeler su potansiyellerinin geliştirilmesini büyük oranda tamamlamışlar ve elde edilen enerji sayesinde sanayilerini geliştirerek, halkın refah seviyesini yükseltmişlerdir.

Türkiye'nin de dâhil olduğu, seksen bir üyesi bulunan ve 1928 y1lında kurulan Uluslararası Büyük Barajlar Komisyonu (İnternational 
Commission on Large Dams-ICOLD)'nun karşı1ı olarak 1997 yılında ortaya çıkan Dünya Barajlar Komisyonu (WCD-World Commission on Dams), bilimsel verilerden uzak ve büyük barajların faydalarını tamamen göz ardı eden raporunu 2000 yılında yayımlamıştır. Aslında büyük barajlara karşı olan hareket 1980 'li yıllar sonunda başlamış ve bu hareketin bir nevi resmi belgesi olan rapor 2000 yılında yayınlanmıştır. Bu raporda en önemli mesaj şu cümlelerle verilmektedir (Bilen, 2003:101): "Baraj inşa edilmesine ilişkin karar günümüzde artık sadece yerel ve ulusal bir karar değildir. Bu konudaki tartışmalar artık yerel bir maliyet ve fayda tespiti işleminden, küresel gelişme stratejileri ve tercihlerinin tartışılması yönünde bir değişime odaklanmıştır."

Baraj inşa etme kararlarında tek yetkinin ulusal devletlerde olmadığg, bu kararların küresel gelişme stratejilerine ve tercihlerine bağlı olduğu tespiti yapılmaktadır. Bu tercihleri gelişmekte olan ülkeler yapamayacağına göre, gelişmiş ülkeler ulusal devletlerin baraj politikalarına müdahale ederek piyasalaştırılması yönünde çaba sarf etmektedirler. Özellikle gelişmiş ülkelerin 1990'lı yıllarda kendi ihtiyaçları olan barajların inşalarını tamamlamasını müteakip Dünya Barajlar Komisyonu'nu kurulması, barajların uluslararası sermayeye açılması açısından düşündürücüdür.

Buna benzer baraj projelerinin Dünyada birçok örnekleri bulunmaktadır. Barajların ve santrallerin yapım aşamasında Dünya Bankası’nın yürüttüğü politikaların 2000'li yıllarda dünya çapında kötü sonuçları olmuştur. Kalite düşüşü, fiyat artışı ve yolsuzluk gibi sorunlar çoğalmış, on binlerce çalışan, işsiz kalmış, su fiyatları üç katına kadar çıkmıştır. Şili”de, Güney Afrika"da ve Yeni Zelanda"da insanlar sokaklara dökülerek uygulamaları protesto etmişlerdir (Shiva, 2003:109-111). Bu projeler daha çok ihaleyi alan firmalara aşırı kar sağlama amacı gütmüştür.

Gelişmiş ülkelerin, Üçüncü Dünya ülkelerindeki baraj yatırımlarına ortak olma yollarından bir tanesi de DB ve IMF politikaları doğrultusunda uygulanan özelleştirmelerdir. Özelleştirme kapsamında uygulanan Yap-İşlet Devret (YİD) modelinin Türkiye'deki ilk örneği "İzmit Şehri Kentsel Su Temini Projesi”dir. 
Proje kapsamında bulunan ham ve arıtılmış su iletim hatları, arıtma tesisi, pompa istasyonları ve ana depolar gibi tesislerin inşaatlarına DSİ tarafından 1996 yılına kadar başlanılamamış, sadece ihalesi yapılan Yuvacık Barajı inşaatı sürdürülebilmiştir. YİD kapsamına alınmasından sonra, proje kapsamında Yuvacık Barajı inşaatı 1998 yılında tamamlanmıştır. 18 Ocak 1999 tarihinden itibaren proje raporunda belirtilen standartlarda arıtılmışsu, İzmit Su ve Atıksu İdaresi (IZZSU) depolarına verilmeye başlanmıştır. Bu şekilde proje çerçevesinde tesisler 18 Ocak 1999 tarihinde ticari işletmeye alınmıştır. 15 yıllık işletme süresi 18 Ocak 2014 tarihinde sona ermiştir(Topçu, 2006:307).

11.04.2002 tarihli Sayıştay Raporu’nda, konu ile ilgili aşağıdaki değerlendirmeye yer verilmiştir:

"YİD modelinin en önemli riski, model kapsamında verilen satın alma garantilerinin kamu kesimini, projelerin YİD modeli ile gerçekleştirilmesi suretiyle elde edilen avantajı aşacak bir ödeme yükümlülüğ̈̈ altına sokması tehlikesidir. Bu risk İzmit Su Projesi’nde gerçekleşmiştir. Şöyle ki; İmit Büyükşehir Belediyesinin, üretilen suyun maliyetinin yüksek olması, bazı endüstriyel kuruluşlar ve çevre belediyelerle su satış bağlantılarını zamanında yapmaması, mali durumunun iyi olmaması gibi nedenlerle, İSAŞ'dan ylllı 142 milyon m3 suyu satın alma taahhüdünü yerine getirememesi sonucunda Hazine vermiş olduğu garanti çerçevesinde iki yıl içinde 387 milyon ABD Doları tutarında su bedelini İSAŞ’a ödemek zorunda kalmıştır" (11.04.2002 tarihli Sayıştay Raporu, s:37).

Pazarlık usulü görevlendirmenin yapıldığı olay, yeterli talep ve fayda-maliyet analizleri yapılmamış olması, rekabetçi bir ihalenin düzenlenmemesi, buna karşılık kamu kesiminin alım ve ödeme garantisi vermesi nedeniyle ciddi olumsuz sonuçlar doğurmuştur (Şimşek, 2006:29).

\section{Baraj Politikaları ve Barajların Yapılış Amaçları}

Susuzluktan en çok etkilenen ülkeler genellikle kurak ve yarı kurak bölgelerde yaşayan Üçüncü Dünya ülkeleri olmuştur. Su yetersizliği, kuraklıklar ve zaman zaman yaşanan su taşkınları çok büyük sorunlar 
yaratmış ve yaratmaya da devam etmektedir. Gıda güvenliği büyük bir problem olmaya devam etmektedir. Gelişmiş ülkelerde elektronik-ticaret ve bilgi teknolojisi bakanlıkları gibi kurumlar oluşturulurken, halen pek çok fakir ülkede sulama alt yapısını geliştirmek için müstakil sulama bakanlıkları veya daha genel anlamda su kaynaklarının geliştirilmesine yönelik su bakanlıkları bulunmaktadır.

Afrika Kıtası'nda pek çok ülkede kırsal ve kentsel nüfusa elektrik enerjisi ulaştırılamamış ve hemen hemen hiçbir sanayi geliştirilememiştir. Afrika'da toplam hidroelektrik potansiyelin sadece \% 1,2'si geliştirilmiştir. 560 milyon insanın yaşadığ 154 Afrika ülkesi yılda 367 milyar KWh hidrolik enerji kullanmasına rağmen, $A B D$ ve Kanada 3,7 trilyon KWh; Batı Avrupa ülkeleri ise 2,7 trilyon KWh elektrik enerjisi tüketmekte, böylelikle bu değerli kaynaklardan, 10 ve 7,5 katı fazla yararlanmaktadırlar. Yalnızca 7 milyon nüfuslu İsviçre’nin ürettiği enerji miktarı tüm Afrika kıtasının altıda biridir (Bilen, 2003:105).

Çin'de bulunan Yangtze Nehri taşkınlarla kontrol edilemediği için yirminci yüzyıl içinde 200000 insan sel sularına kapılarak hayatını kaybetmiştir. 1992 yılında İndüs Nehri taşkınları 1034 kişinin ölümüne ve 105 milyon USD zarara yol açmıştır. 1972-1996 yılları arasında WCD’nin belirttiğine göre taşkınlardan can kaybı ve maddi zarar şeklinde etkilenen insan sayısı 65 milyondur. Bu örnek taşkın önleme amaçlı barajlara duyulan ihtiyacı net olarak göstermeye yetmektedir. Büyük barajların \% 31'i gelişmiş ülkelerde, \% 46’sı Çin'de, \% 9 'u ise Hindistan'da inşa edilmiştir. Tüm Afrika kıtasında ise 47655 adet büyük barajdan ancak \% 3'ü bulunmaktadır. Hidrolik enerjinin \% 60’’nı (1999 yılında), dünya nüfusunun beşte birinin yaşadı̆̆ \% 40’’nı ise dünya nüfusunun \% 80'inin yaşadığ gelişmekte olan veya Üçüncü Dünya ülkeleri üretmiştir. Ekonomik kalkınmanın sağlanması temel bir insan hakkıdır ve enerji olmadan kalkınmaya imkân yoktur (Bilen, 2003:106).

$A B D$ ve Kanada'da toplam büyük baraj sayısı 7368 'dir. ABD'de sadece Colorado Nehri havzasında, bir kısmı gerek su depolama hacmi 
gerekse yükseklik bakımından dünya sıralamasında en üst sıralarda yer alan 51 baraj bulunmaktadır. Yukarı Missisipi havzasında taşkın zararlarını önlemek amacıyla toplam depolama hacmi 49 milyar m3 olan 66 baraj inşa edilerek Türkiye'nin toplam yüzölçümünden büyük 956000 km2'lik bir alan kontrol altına alınmıştır. ABD 1960- 1970 yılları arasında yılda yaklaşık 180 baraj inşa etmiştir (DWP, 2013).

Avrupa ülkelerinde 4277 barajdan 1200 adedi İspanya'da bulunmakta ve bunu beş yüzden fazla barajla Fransa, İngiltere ve İtalya takip etmektedir. Avrupa Birliği ülkelerinde elektrik enerjisinin \% 50'si su kaynaklarından sağlanmaktadır. Norveç’te bu değer \% 99'dur (www. eia.gov. 2012). Norveç çok zengin doğalgaz kaynaklarına sahip olduğu halde elektrik ihtiyacının tamamına yakınını sudan sağlamakta ve doğal gazını ise Avrupa ülkelerine satmaktadır.

Avrupa Birliği ülkelerinin nüfusu, yüzölçümü ve su potansiyeli Türkiye ile karşılaştırıldığında, yeterli bir gelişme düzeyine henüz ulaşamadığımız görülmektedir. Ülkemizin teknik olarak geliştirilebilir hidroelektrik potansiyeli yılda 216 milyar KWh olup, bugünkü koşullarda ekonomik olarak yapılabilir bulunan projelerin üretebileceği toplam enerji ise yılda 125 milyar KWh'dir. Barajların yapılması ile ulaşılmak istenen amaç akarsuların akış rejimlerini düzenlemek hem de elektrik enerjisi üretmek içindir. Ebatları belirli bir hesaba dayanmaktadır. İhtiyaç duyulan büyüklükte yapılması gereken yapılar olup gerekenden büyük ve hacimli yapıldıklarında, yapılan yatırımdan tam verim alınamaz ve kaynak israfına sebep olurlar. Barajların görevleri akışı bozan aşkın suyu baraj haznelerinde bekletip, ihtiyaç duyulan zamanda akıtılmasını sağlayarak düzenli bir akış rejimine ulaşmaktır.

\section{3. Çoruh Nehri Hidroelektrik Gelişme Planı}

Yusufeli’nin de içinde yer aldığ Çoruh Havzası, ülkemizin 26 havzasından biri olup, su potansiyeli bakımından 4. sırada bulunmaktadır. Çoruh nehri ve kollarından oluşan havzanın yağış alanı yaklaşık 20000 kilometrekare ve yıllık ortalama su potansiyeli 6540 milyon metreküp 
olup, ülkemiz hidroelektrik enerji potansiyelinin \% 10’unu teşkil etmektedir. Yıllık ortalama akışın \% 60'lık bölümü 3 ayda akan Çoruh nehrinin tabii akış rejimi düzenli olmadığından enerji potansiyelinin tam olarak değerlendirilebilmesi için ana kol ve yan kollar üzerinde büyük depolamalı barajların yapılması mecburi olmaktadır (Açıkalın, 2007:35-36).

Çoruh nehrinin mevcut su potansiyelinden yararlanarak hidroelektrik enerjisi üretmek amacıyla Elektrik İşleri Etüd İdaresi Genel Müdürlüğü tarafından 1960’lı yıllarda başlatılan ilk çalışmalar 1969 yılında tamamlanarak "Çoruh Havzası İstikşaf Raporu” hazırlanmıştır. 1982 yılında hazırlanan "Çoruh Nehri Hidroelektrik Gücü Geliştirme Planı" çalışmaları neticesinde ana nehir üzerinde entegre basamak şeklinde gerçekleştireceği 10 baraj projesi bulunmaktadır. Yusufeli Barajı ve HES bu projelerden sadece birisidir. Bu projeler, Türkiye'nin toplam enerji üretiminin yaklaşık \% 8'ini, hidroelektrik santrallerinden elde edilen toplam enerjinin ise yaklaşı \% 34'ünü oluşturacaktır. Nehrin en yukarı kısmındaki Laleli ile en aşağ 1 kısmındaki TBMM 85. Yıl Muratlı baraj yerleri arasındaki 1,430 m'lik kot farkı; 2,536 MW'lik kapasiteyle yılda 8,322 GWh'lik elektrik üretimi için kullanılacaktır.

Çoruh Nehri hidroelektrik projeleri üç bölüm olarak geliştirilmiş olup (Açıkalın, 2007:35-36) bunlar şunlardır:

Yukarı Çoruh Havzası, 1480 kotu ile 710 kotu arasında toplam 770 m. su yükü ve 5 barajdan (Laleli, İspir, Güllübağ, Aksu ve Arkun) oluşmaktadır.

Orta Çoruh Havzası, 710 kotu ile 392 kotu arasında toplam $318 \mathrm{~m}$. su yükü ve 2 barajdan (Yusufeli ve Artvin) oluşmaktadır.

Aşağı Çoruh Havzası, 392 kotu ile 56 kotu arasında toplam 336 m. su yükü ve 3 barajdan (Deriner, Borçka ve Muratlı) oluşmaktadır. Membadan mansaba doğru barajların kapasitelerini ve yıllık üretimlerini çizelgede görmekteyiz. 
Çizelge-1: Çoruh Nehri'ndeki Barajların Kurulu Güçleri ve Yıllık Elektrik Üretimleri

\begin{tabular}{|l|c|c|}
\hline Baraj Adı & Kurulu Gücü & Ylllık Elektrik Üretimi \\
\hline Laleli & $99 \mathrm{MW}$ & $204 \mathrm{GWh}$ \\
\hline İspir & $54 \mathrm{MW}$ & $327 \mathrm{GWh}$ \\
\hline Güllübağ & $84 \mathrm{MW}$ & $285 \mathrm{GWh}$ \\
\hline Aksu & $120 \mathrm{MW}$ & $344 \mathrm{GWh}$ \\
\hline Arkun & $222 \mathrm{MW}$ & $788 \mathrm{GWh}$ \\
\hline Yusufeli & $540 \mathrm{MW}$ & $1705 \mathrm{GWh}$ \\
\hline Artvin & $332 \mathrm{MW}$ & $1026 \mathrm{GWh}$ \\
\hline Deriner & $670 \mathrm{MW}$ & $2118 \mathrm{GWh}$ \\
\hline Borçka & $300 \mathrm{MW}$ & $1039 \mathrm{GWh}$ \\
\hline Muratlı & $115 \mathrm{MW}$ & $444 \mathrm{GWh}$ \\
\hline TOPLAM & $2536 \mathrm{MW}$ & $8322 \mathrm{GWh}$ \\
\hline
\end{tabular}

Kaynak: www.dsi.gov.tr.

Bu barajlardan TBMM 85. Yıl Muratlı Barajı 2005 yılında, Borçka Barajı 2007 yılında, Deriner Barajı 2013 yılında işletmeye alınmıştır. Yusufeli Barajı’nın inşaatına 21 Aralık 2012 tarihinde başlanılmıştır. Hatta Orman ve Su İşleri Bakanı olan Prof.Dr.Veysel Eroğlu'nun Su Dünyası Ocak 2007 sayısındaki yazıda konuşması "Bütün yeni başlangıçlar insana şevk, heyecan ve umut verir" cümlesiyle başlamakta, 2007 yılında da çalışmaya "son sürat" devam edeceklerini belirtmekte ve üçüncü cümlesinde ise "Mavi Tünel, Yusufeli Barajı" gibi büyük projelerin temel atma törenlerinin yapılacağını müjdelemektedir. İki sayfalık yazıda bizi ilgilendiren satırları okuduğumuzda (Eroğlu, 2007:7):

"Yeni yılda Türkiye'nin uzun vadeli enerji hedefleri çerçevesinde çok önemli bir yer tutacak olan Borçka Barajı̉nı hizmete alıp, Çoruh nehrimizi dizginleyecek 4. tesis olan Yusufeli barajının temelini atacağız. Bekir Karadeniz’in Gecikmiş Şiirler'de, “Toprak az, gökyüzü boldu 
doğduğum yerde/ Topraktan gerçeği, gökyüzünden düşlemeyi öğrendim...” diye anlattığ 1 Çoruh vadisi bilindiği üzere ülkemizin en dağlık bölgelerinden biridir. Dünyanın en hızlı akan nehirlerinden biri olan Çoruh'un derinlemesine yardığı vadide coğrafi şartlar insan hayatını zorlaştırır. Şimdi ise bu vadi insan emeğiyle dolacak, Çoruh'un azgın suları artık bölge insanına iş, aş ve ışık olarak dönecek." denilmektedir.

\subsection{Yusufeli Barajı ve Hidroelektrik Santrali'nin Gelişim Süreci}

Yusufeli Barajı ve Hidroelektrik Santrali (HES), DSİ Genel Müdürlüğü’nün Çoruh Nehri üzerinde gerçekleştireceği 10 projesinden biridir. Yusufeli Barajı ve HES, tamamlandığında temelden $270 \mathrm{~m}$ yüksekliği ile dünyanın en yüksek kaya dolgu barajlarından biri olacaktır. Tesisin Türkiye enerji üretimine 540 MW'lik (3 x 180 MW) kurulu güç ile katkıda bulunması beklenmektedir. Yüksek kurulu gücü ve yıllık elektrik üretimi (1,705 GWh/yıl) ile ülkemiz yıllık enerji ihtiyacının \% 0.6’sını karşılayacak ve Türkiye'nin uzun vadeli enerji hedefleri çerçevesinde önemli bir yere sahip olacağı belirtilmektedir.

Yusufeli Projesi için çalışmalar sırasıyla (Sarıkız, 2008:4);

Yusufeli Projesi için çalışmalar sırasıyla (Sarıkız, 2008:4) şunlardır:

- 1970’lerde, Enerji ve Tabiî Kaynaklar Bakanlığı Elektrik İşleri Etüt İdaresi Genel Müdürlüğü tarafından başlatılmış, 1982'de projeyi de kapsayan Çoruh Nehri Hidroelektrik Gelişme Master Plânı hazırlanmış, 1986 'da fizibilite raporu tamamlanmış, 1990' da nihai projeler tamamlanmış ve onaylanmıştır.

- 1996 yılında Fransa, Avusturya ve Türkiye arasında gerçekleştirilen bir protokolle, barajların birlikte inşasına dair bir anlaşma yapılmıştır. Aynı zamanda Türkiye’nin Fransa ile yaptığı bir protokol uyarınca, Yusufeli barajının yapımı boyunca ve gelecekte de devamlı Fransız inşa firmalarının yer alması konusunda anlaşmaya varılmıştır.

- 1997 yılında Fransız firması Spie Bagtalaneous ve İngiliz firması Amec, baraj inşası için vaatler almışlardır. 
- 1998 yılında Çevre ve Orman Bakanlığı, Çevresel Etki Değerlendirme (ÇED) çalışması için firma Encon'u görevlendirmiş, Bakanlık, bu çalışmanın tamamlanmasından kısa bir süre önce görevi durdurmuştur. Son aşama da ise planların yapıldığ 1990 'l $l_{1}$ yıllarda böyle bir çalışmaya aciliyet duyulmadığını, Türk kanunlarına göre Yusufeli-Artvin barajlarının ÇED raporuna ihtiyacı olmadığını dillendirmeye başlamışlardır.

- 1999-2000 SAHARA-Engineering adlı bir kuruluş Yusufeli'nin yeni yerleşim yerini araştırmak üzere bir çalışma yürütmüş, Yusufeli'nden $500 \mathrm{~m}$ daha yüksekte ve taşlık bir alanın yeni yerleşim yeri olmasını kararlaştırmıştır. Yöre sakinleri, yeni yerleşim alanında yaşamanın mümkün olmadığını dile getirerek sonucu tartışmaya başlamışlar. Bu yüzden de, Devlet Su İşlerinin (DSİ) yaptığı bir halk yoklamasında halkın \% 60’ı ilçeyi terk etmek istemediklerini söylemiştir. Halk, yeni yerleşim yerinin elverişli şartlarda olması halinde başka yerlere göçmektense kalmayı istediklerini ve kendi bölgelerinde yaşamayı tercih ettiklerini bildirmiştir.

- 2001-2002 arasında çeşitli kamu organizasyonları (Les Amis de la Terre, die Stiftung France Libertés, Friends of the Earth UK, The Corner House UK, Kurdish Human Rights Project und die Erklärung von Bern Schweiz), uluslararası standartların ağır şekilde ihlal edildiğine dair dikkatleri konuya çekmek üzere bir kampanya başlatmıştır.

- 2002 Nisan ayında yörede oluşturulan bir misyon, projenin, uluslararası standartların ufak bir kısmını dahi içermediğini, ne çevresel etkileri ne de yerleşim planları konusunda herhangi bir çalışmayı kapsamadığını onaylamıştır.

- 2002 Aralık ayında Fransız ihracat riziko sigortası COFACE, Türkiye'nin Çevresel Etki Değerlendirmesi (ÇED) yapmayı istememesi nedeniyle projeyi geri çevirmiştir.

- Fransız firması Spie ve İngiliz firması Amec, barajın olumsuz çevresel etkilerinin ağır cezai yüklerinden korktukları için projeden çekilmiştir. Böylece Yusufeli barajı birinci kez masadan kaldırılmıştır. 
- 2005 yılında T.C. Enerji Bakanlığı yeni bir inşa konsorsiyumu oluşturmuştur. Alstom (Fransa, İsviçre) ve Doğuş (Türkiye) nakliye ve inşa ile görevlendirilmiştir. Resmi olarak Çevresel Etki Değerlendirme (ÇED) zorunluluğu olmadığ larına göre 1990 öncesi planlanan projeler için gerekmiyor), konsorsiyum, Türk Çevre Değerlendirme bürosu olan Encon'a bu görevi kendisi vermiştir.

- 2005 sonbaharı Encon, barajla ilgili çeşitli görüşlerin yer aldığ küçük bir broşür çıkartmıştır.

- 2006 yılı Ağustos ayında Devlet Su İşleri (DSİ) ilçede Yusufeli projesi hakkında bilgilendirme toplantısı yapmıştır.

- 2006-2007 yıllarında DSİ kamuoyuna, Dünya Bankası Grubu ve OECD normları doğrultusunda, inşa firmalarının görevlendirmeleriyle elde edilen değişik Çevresel Etki Değerlendirme raporları ve göç planlarını açıklamıştır.

- 2007 yılı Şubat ayında İsviçre Federal Konseyi 14 Şubat 2007 de Alstom’a (İsviçre) jeneratör nakliyesi için 115 milyon İsviçre Frankı tutarında ihracat riziko garantisi verilmesini vaat etmiştir. Vaat edilen garanti ise ek bir yükümlülükle, Dünya Bankası standartlarına uygun bir çevre raporu ve yerleşim yeri planının yerine getirilmesi şartına bağlanmıştır.

Yusufeli Barajı, Hükümetler Arası İkili İşbirliği çerçevesinde, Türkiye Cumhuriyeti Bakanlar Kurulu Kararnamesi uyarınca DOĞUŞ İnşaat ve Ticaret A.Ş. Liderliğinde; ALSTOM, COYNE \& BELLIER ve DOLSAR'dan oluşan konsorsiyum tarafından inşa edilecek olup, finansman kısmen uluslararası finans kuruluşlarından sağlanacaktır (www.dsi.gov.tr).

Proje, işe başlama tarihinden itibaren 88 ay (yaklaşık 7.5 yll) içinde tamamlanacak ve işletmeye alınacaktı. Tesis inşaatına 2006 yılında başlaması ve 2013 yılında tamamlanması öngörülmüştü. Baraj inşaatın başlamasından 79 ay sonra su tutmaya başlayacaktı, Artvin -Erzurum ve Artvin- Bayburt relokasyon yollarının yapımı inşaat faaliyetlerinin 
başlamasından 75,5 ay sonra tamamlanacaktı, böylece relokasyon yolları su tutulmadan 3,5 ay önce tamamlanmış ve hizmete girmiş olacaktı fakat yerel halkın tepkileri nedeniyle inşaata 21 Aralık 2012 tarihinde başlanmış ve gecikmeli olarak inşaatlar devam etmektedir. Yusufeli projesi için toplam 855000000 ABD tutarı kredi sağlanacaktır. Proje yatırımı için gerekli fon, DSİ'nin müteahhidi olacak konsorsiyum tarafından, ulusal ve uluslararası finans kaynaklarından sağlanacaktır.

Yusufeli projesi Artvin ilinin tahmini 40 kilometre güneybatısında ve Çoruh Nehri üzerindeki ilçe merkezinin $10 \mathrm{~km}$ mansabında yer almaktadır. Ülkemiz sınırları içinde Çoruh Nehrinin uzunluğu $390 \mathrm{~km}$ ve su toplama alanı 19,750 kilometrekaredir (Tüm Türkiye'nin yaklaşı \% 2,53’üdür). Bu bağlamda projeyi gerçekleştirecek Konsorsiyumun yapısı aşağıdaki şekildedir:

Çizelge-2: Yusufeli Projesini Gerçekleştirecek Konsorsiyumun Yapısı

\begin{tabular}{|c|c|c|}
\hline & Firma Adı & Rolü \\
\hline $\begin{array}{l}\text { İnşaat İşleri } \\
\text { Grubu }\end{array}$ & $\begin{array}{l}\text { Doğuş İnşaat ve Tic. A. Ş., } \\
\text { İstanbul/Türkiye }\end{array}$ & $\begin{array}{l}\text { Konsorsiyum } \\
\text { Lideri }\end{array}$ \\
\hline $\begin{array}{l}\text { Elektromekanik } \\
\text { İşler Grubu }\end{array}$ & $\begin{array}{l}\text { ALSTOM İsviçre Ltd. Baden/ } \\
\text { İsviçre } \\
\text { ALSTOM POWER } \\
\text { Hydraulique Levallois- } \\
\text { Perret/Fransa } \\
\text { ALSTOM POWER Hydro } \\
\text { Grenoble/ Fransa } \\
\text { ALSTOM Brazil Ltda Sao } \\
\text { Paulo/Brezilya }\end{array}$ & $\begin{array}{l}\text { Elektromekanik } \\
\text { İşler Grubu } \\
\text { Lideri }\end{array}$ \\
\hline $\begin{array}{l}\text { Mühendislik } \\
\text { ve Müşavirlik } \\
\text { İşleri Grubu }\end{array}$ & $\begin{array}{l}\text { Coyne \& Bellier (C\&B) } \\
\text { Grennevilliers Cedex/Fransa } \\
\text { Dolsar Mühendislik Ltd. } \\
\text { Şirketi, Ankara/Türkiye }\end{array}$ & $\begin{array}{l}\text { Mühendislik } \\
\text { ve Müşavirlik } \\
\text { İşleri Grubu } \\
\text { Lideri }\end{array}$ \\
\hline
\end{tabular}

Kaynak: www.dsi.gov.tr. 


\subsection{Yusufeli Yeniden Yerleşim Eylem Planı (YYEP)}

Yusufeli Barajı ve HES’in inşaatı neticesinde oluşacak baraj gölü, Yusufeli ilçe merkezini ve 3 köyünü tamamen su altında bırakacaktır. Ayrıca 16 köy ve/veya arazileri de kısmen su altında kalacaktır. Bu sebeple, Yusufeli Projesi için bir Yeniden Yerleşim Eylem Plânı (YYEP) hazırlanması çalışmaları ilk olarak proje sahibi DSİ tarafından Ağustos 2000'de başlatılmış; bu çalışmaların neticesinde YYEP Raporu Şubat 2001'de tamamlanmıştır. Bu tarihten sonra Türk Mevzuatı́nda kamulaştırma ve yeniden yerleşim konularında önemli değişiklikler meydana gelmiş ve uluslararası kredi kurumlarının standartları da revize edilmiştir. Mevcut YYEP Raporunun yenilenmesi için çalışmalar Temmuz 2004'te başlatılmış ve Türk Mevzuatı, Dünya Bankası Grubu ve OECD standartları doğrultusunda YYEP raporu tamamlanarak DSI'nin internet sitesinde Temmuz 2006 tarihinde yayınlanmıştır. Bu raporda detaylı olarak açıklandığı üzere Yusufeli ilçe merkezi, mevcut Yusufeli’ne yaklaşık $500 \mathrm{~m}$ mesafedeki Yansıtıcılar ve Sakut Deresi mevkiine (Yusufeli Yeniden Yerleşim Alanı) taşınacak olup, ilgili Bakanlar Kurulu Kararı Resmi Gazetede 25 Nisan 2006 tarihinde yayınlanmıştır (www.dsi.gov.tr.).

\section{Yusufeli Tarihi ve Kültürüi}

Yusufeli, Artvin İlinin önemli ilçelerinden biri olup, ilin yüzölçümünün üçte birini kaplamaktadır. Çoruh nehrinin kolları tarafından bölünen beş ana bölge içinde yüze yakın çay ve dere vadilerinde yerleşik her biri en az bin yıllık, 61 köyün hemen hemen ortasında bir yerdedir. Yusufeli, Artvin'in, dışa en çok göç veren ilçesidir. İlçenin nüfusu 1990 yılında 37060 iken, 2000 yılında 29133'e ve 2008 yılında 22220'ye gerilemiştir(www.artvin.gov.tr). Baraj yapımı, ilçe nüfusunun büyük oranda diğer illere göç vermesine sebep olmuş ve nüfus artışını engellemiştir.

İlçe halkı tarım, gurbetçilik ve hızla gelişen turizmle geçinmektedir. Toprakları mineral yönünden son derece zengin, senede 9 kere yonca ve üç kere kültür bitkisi ürünü alınabilen Akdeniz dışında Akdeniz iklimine sahip tek bölgedir. İlçe hudutları içinde kültür bitkisi olarak limon, zeytin, pirinç, buğday, çavdar, kayısı, elma, armut, kiraz dâhil her 
çeşit Anadolu meyvesi yetişir. Dağların da her tür yabani meyve bitkisi ve çok çeşitli yabani hayvan mevcuttur. Mayıs ayından Eylül ayı sonuna kadar taze kiraz yenebilmektedir. Vadiler tabii bir sera olup Çoruh Vadisi yamaçlarında suyun gidebildiği her taşın üstü her bayır Yusufeli’li için tarım alanıdır. Bölge pirinçle buğdayın aynı tarladan aynı yılda alındığı tek yer olup kendine ait Yusufeli zeytini, Yusufeli pirinci ve Yusufeli üzümü ve diğer kültürel bitkilerle bölge insanı tarım hayatını sürdürmektedir. Arıcılık, tarım, sebze ve meyvecilik, büyük ve küçükbaş hayvancılık geleneksel geçim kaynaklarıdır.

İl turizm yetkililerinin tahminlerine göre önümüzdeki 10 yıl içinde, Yusufeli bölgesine ve inanılmaz güzellikteki Kaçkarlar'a gelecek turist sayısı bugün 40000 iken en az 500000'e ulaşacaktır. Alternatif turizmin iki kolu olan dağ yürüyüşü (trekking) ve salcılık (rafting) bir arada yalnız Yusufeli’nde yapılabilmektedir. Çoruh Nehri salcılıkta (rafting) dünyanın en ekonomik birinci ve en heyecan verici ikinci nehridir. Ayrıca bölge tarihi eser zenginidir ve dini turizm hareketleri de artmaya başlamıştır. Kış turizmi, detox kürü turizmi, dağ yürüyüşü (trekking), yayla şenlikleri turizmi açısından Yusufeli inanılmaz zenginliklere sahiptir. "Helikopterle dağ kayağı" Yusufeli köylerinde başlamıştır, mezraları ve köyleri henüz keşfedilmemiş yerlerdir.

Türkçe, Hemşin, Lazca ve Gürcüce konuşulan diller arasındadır. Müzikleri zengin bir tarih ve kültürü barındırmaktadır. Tulum yöreye özgü müzik enstrümanıdır. Dize konularak çalınan kemençe ile akordiyon da yöreye özgü çalgı aletlerindendir. Özellikle kadınların giydiği rengârenk yöresel kıyafetler ve başlarına bağladıkları süslü başlıklar da yörenin meşhur olmuş renkli çeşitliliğini yansıtmaktadır (Sarıkız, 2008:2).

Tarihi veriler, Yusufeli’ye ilk göçlerin bakır çağında başladığını, s1radağlarının doğu ile batı arasındaki stratejik önemi nedeniyle, Persler, Romalılar, Bizanslar, Ermeniler, Osmanlılar ve Ruslar arasında savaşlara sahne olduğunu göstermektedir. 9. yy.dan 11. yy.a kadar Gürcistan prensleri hüküm sürmüş ve kiliselerle manastırlar onların zamanında yapılmıştır. 


\section{Yusufeli Projesine Karşı Halkın Tepkisi}

- 2001 yılında Yusufeli Kültür Derneği, Çevresel Etki Değerlendirmesi (ÇED) olmadığı gerekçesiyle Enerji bakanlığına projenin durdurulması için başvuruda bulunmuştur.

- 2002 yilında Yusufeli’ni Koruma ve Kültür Derneği, baraj karşıtlarından 6000 imza toplamıştır.

- 2002 yılı Şubat ayında Yusufeli Kültür Derneği, İdare Mahkemesinde Çevresel Etki Değerlendirme (ÇED) raporu ve yeni yerleşim planı olmaması gerekçesiyle projenin durdurulması istemiyle dava açmıştır.

- 2005 yılı Temmuz ayında Danıştay 10. Dairesi aşağıdaki gerekçelerle proje ve ihalelerin durdurulması ve iptal edilmesi kararını vermiştir. Mevzu bahis olan hali hazırdaki ÇED raporu Türk kanunlarına göre geçerli değildir ve ÇED raporlarında aranan kriterleri içermemektedir. Bir ÇED raporu için T.C. Enerji Bakanl1ğının görevlendirme yapması gerekmektedir ki; söz konusu olayda mevzu bahis işlem yapılmamıştır.

- 2005 yılı Temmuz ayında Enerji bakanlığı ve DSİ karara itiraz etmiştir. Böylece dava Danıştay İdari Davalar Kuruluna intikal etmiştir.

- 2005 yılı Ağustos ayında Danıştay İdari Davalar Kurulu 6 ret, 23 kabul oyuyla temyiz kararını vermiştir. Buna göre "Proje 1990'dan önce planlandığı ve o zamanlarda ÇED raporu yükümlülüğü olmadığı için proje inşa edilebilir" denilmiştir.

- 2006 yılı Şubat ayında Avukat Recep Akyürek, 100 Yusufeli'li davacıyla birlikte son karara itiraz etmişler ve dava Yüksek İdare Mahkemesi (Danıştay)'ne intikal etmiştir.

- 2007 yılı Ocak ayında Ankara Yüksek İdare Mahkemesi, Uluslararası standartlara göre bir ÇED raporuna gerek yoktur kararı vermiştir.

- 2007 yılı Ağustos ayında Yusufeli Kültür Derneği, günlerce süren baraj karşıtı mitingler düzenlemiştir. 
Devlet tarafından yapılan kamulaştırmalar ile halkın maddi kaybı giderilmeye çalışılmaktadır. Özellikle sel ve heyelan riski taşıyan bölgelerdeki halk zemini sert olan daha emniyetli bölgelere taşınmaktadır. Ülke çıkarlarına hizmet eden böyle yatırımlara halkın destek vermesi gerekirken, ülkemizin gelişmesini istemeyen ülkeler tarafından halk yönlendirilmekte ve yatırımlar geciktirilmektedirler.

\section{Yusufeli Projesinin Etkileri}

$\mathrm{Bu}$ projenin mimari yapısı, maliyet analizi ve çevresel kayıplar göz önüne alındığında fayda ve zararları daha kolay anlaşılmaktadır.

\subsection{Yusufeli Barajı'nın Mimari Yapısı}

Çoruh Havzası üzerinde inşa edilecek en büyük baraj olacak Yusufeli Barajı ve Hidroelektrik Santrali, aynı zamanda çift eğrilikli beton kemer kategorisinde dünyanın üçüncü yüksek barajı olacaktır (www.limak.com.tr). Bu baraj dolayısıyla $118 \mathrm{~km}$. viyadüklü, tünelli; iller arası, ilçeler arası ve köy yolları yapılacaktır. Yusufeli ilçesi aşırı engebeli bir arazi yapısına sahip olup tarım yapılabilen yeterince düz arazi bulunmamaktadır. Yusufeli Barajının yapımı ile 16 köy ve bir ilçe merkezi etkilenecektir. Barajla bölge 5 parçaya bölünse dahi çevre bağlantı yolları ile bölgeler tekrar birbirine bağlanacaktır.

Bu barajın yapılması planlanan bölge aşırı yağış alan bir bölge olmakla birlikte bundan dolayı toprak kaymalarının sık sık yaşandığı bir coğrafyadır. Dolayısı ile yerleşim yerine uygun bir bölge değildir. Yeni yerleşim yerinin kayalık bölge olan Yansıtıcılar ve Sakut Deresi mevkiine yapılması planlanmaktadır. Aşırı yağış alan bölge ise baraj yapımı ile ülke ekonomisine kazandırılmış olacaktır.

Başlangıçta yüksekliği, Yusufeli ilçesini su altında bırakmaz iken baraj yapımına başlayınca yüksekliği 275 metreye çıkartılmış ve böylece ilçe merkezi sular altında kalmıştır. Baraj, 275 metre yükseklikte, kil çekirdekli kaya dolgu tipinde olup, bu yükseklikte Türkiye'de bu tip bir baraj ilk olma özelliğini taşımaktadır. Türkiye’nin bugüne kadar inşa 
ettiği tek büyük kaya dolgu barajı 169 metre yüksekliğindeki Atatürk barajıdır. Gövde dolgusu 7 yıl sürmüştür.

\subsection{Yusufeli Barajı ve Hidroelektrik Santrali'nin Maliyet Analizi}

Bu barajın yapımına 21 Aralık 2012 tarihinde başlanmıştır. Limak-Cengiz-Kolin tarafından yapılacak olan Yusufeli Barajı ve Hidroelektrik Santrali projesi; Doğu Karadeniz Bölgesi’nde, Artvin'in 70 kilometre güney batısında Çoruh Nehri üzerinde yer almaktadır. Kamulaştırmalar nedeniyle 18000-20000 kişinin yeni yerleşim yerlerine nakli gerekmektedir.

Aynı türden gövdeye sahip olan Atatürk barajının yapım hızı esas alınarak, Deriner barajındaki keşif artışları, bu barajın Deriner'den farklı keşif artırıcı unsurları (daha yüksek olması, daha karışık jeolojik bir yapıya oturtulması, şantiye konuşlanma sahalarının yapım yerine uzaklığı, çekirdek kili olarak düşünülen toprakların karışım yapılmadan kullanılamaz olması, derivasyon tünellerinin üç adet olması gibi) ile bir ilçe merkezinin yeniden inşası, Erzurum-Karadeniz ulaşımının en güvenli güzergâhının yok olması gibi hususlar maliyeti artırıcı etkiler olarak göz önüne alınmalıdır.

DSİ Genel Müdürlüğünce 13.08.2012 tarihinde ihalesi yapılan Yusufeli Barajı ve HES İnşaatı Limak, Cengiz ve Kolin firmalarının oluşturmuş olduğu LCK Yusufeli Adi Ortaklığına 486.875.000 TL ihale bedeli ile ihale edilmiştir (www.artvindefterdarligi.gov.tr). Fakat bu bedel sadece baraj gövdesi ve santralin ihale bedelidir. Bunun içine çevre, ticari, turizm, kültürel, vahşi hayvan ve bitki varlıkları ve sosyal kayıplar dâhil edilmemiştir. Muratlı ve Borçka barajlarının ihale bedellerinin sürekli artmış olmasından dolayı bu barajın da ilk ihale bedelinin sürekli artacağı değerlendirilmektedir. Ülkemizde özellikle hidrolik enerji üretimine yönelik yatırımlar teşvik edilmektedir. Fakat özel sektör tarafından kar marjı yüksek olanlar rağbet görmekte, kar marjı düşük olanlar tercih edilmemektedir. DSİ tarafından yapılan ihalelerde keşif bedelleri 
yatırımın her boyutunu maliyet hesaplamalarına dâhil etmeli ve sonradan devleti sıkıntıya sokacak ihale artışları yaşanmamalıdır.

\subsection{Yusufeli Barajı'nın Yapılmasıyla Ortaya Çıkacak Kayıplar}

Ülkemizin eşsiz güzelliklere sahip olan Karadeniz bölgesinde bulunan Çoruh Nehri ve Çoruh Vadisi birçok endemik hayvan ve bitki türünü barındırmaktadır. Aynı zamanda Karadeniz bölgesi de ülkemizin en çok yağış alan bölgesidir. Dolayısıyla hidroelektrik enerjiyi en çok üretebileceğimiz bölge de burasıdır. Yapılan yatırımlarda bölgenin doğasına zarar verilmeden yatırımların yapılması gerekmektedir. Aşağıda yatırımın tamamlanması neticesinde net olarak görebileceğimiz muhtemel kayıplar sıralanmıştır.

1. Çevresel Kayıplar:
a. Endemik bitki kayıpları,
b. Endemik hayvan ırklarının ve varlığının kaybı,
c. Sosyal kültürel değerler,
d. Turizm imkânları kayıpları,
e. Çevredeki ticari kayıplar (Çoruh vadilerindeki kapanan ticari işletmeler),

2. Kamu arazilerinin ve yeraltı zenginliklerinin kaybı; tahminen 22 $\mathrm{km}^{2}$ arazi ve madenler,

3. Diğer kayıplar,
a. Üreticilikten, tüketiciliğe geçen insanların yarattığı kayıp,
b. Büyük şehirlere göçen insanların uyum sorunları, o şehirdeki yaşama olumsuz etkileri,
c. Kentten köye tersine göç için imkânların yok edilmesi,

4. Uluslar arası sözleşme yükümlülükleri. 
Yukarıda bahsedilen söz konusu kayıplar neticesinde ülkemizin enerji ihtiyacını karşılamak için ne kadar enerji üretildiği önem kazanmaktadır. Yatırımın optimum faydayı sağlayabilmesi için faydasının kaybettirdiklerinden fazla olması gerekir ki Yusufeli örneğinde de yatırımın toplumsal faydası nispeten daha yüksek olabilir.

\section{Yusufeli Barajı ve Çoruh Nehrinin Geleceği}

Yusufeli Barajının akış yukarısından itibaren altıncı baraj ve gövde yüksekliğinin 275 metre olması sebebiyle taşkın koruma ve enerji üretimi amacına hizmet edecektir. Doğu Karadeniz in bol yağış alan bir bölgesinde bulunan Çoruh Nehri ülkemiz enerji ihtiyacının \% 8'i gibi büyük bölümünü karşılayacaktır. Bölgenin aşırı engebeli yapısı maliyet artışı getirmesi sebebiyle özel sektör yatırımlarını çekmemektedir. Yamaç tipi santraller Karadeniz bölgesi için uygun yatırım şekilleri olabilirler. Hatta yamaç tipi santrallerin yapımı kamu kesimi yerine özel sektör tarafından yapılarak üretilen enerjinin kamu tarafından alım garantisi verilerek alınması hem maliyetleri düşürecek hem de bölge halkının istihdamına katkı sağlayacaktır. Fakat bölge halkının ekonomik durumu zayıftır ve bu santrallerin yapımına uygun değildir. Ancak özel sektör tarafından çok sayıda yamaç tipi santrallerin yapılması ve hepsinin rasyonel işletilememesi durumunda su israf olacak ve beklenilen faydayı sağlayamayacaktır. Ölçek ekonomisi uyarınca devletler küçük ölçekli işletmeler yapmak yerine büyük ölçekli işletmeler yaparak maliyetleri azaltma yoluna gitmektedirler.

Özellikle sonbahar ile ilkbahar mevsimleri arasinda meydana gelen aşırı yağışlardan dolayı Çoruh Nehri havzasında su taşkınları kontrol altına alınacak ve havzada yaşayan halk sel felaketi yaşamayacaktır. Barajların yapımı ve kamulaştırmalar ile nehir havzalarında yaşayan halk daha emniyetli yerleşim yerlerine taşınacak, sel ve heyelana maruz kalan bölgeler boşaltılmış olacaktır. 


\section{Sonuç}

Çoruh Nehri ve Yusufeli Barajı ürettiği enerji ile ülkemizin yıllık enerji üretiminin \% 8'ini hidroelektrik enerjisi üretiminin \% 34'ünü karşılayarak enerji ihtiyacımızın azalmasına katkı sağlayacaktır. Avrupa Birliği ülkeleri enerji ihtiyaçlarının \% 50’sini su kaynaklarından sağlamakta, Norveç ise \% 99’unu su kaynaklarından sağlamaktadırlar. Ülkemizde ise bu oran \% 24 civarındadır. Ülkemizin biran önce enerji üretiminde kullanılabilir su potansiyelini artırması ve kullanıma sokması gerekmektedir. Ülkemizin Avrupa ülkeleri ile kıyasladığımızda çok zengin yeraltı kaynakları bulunmamaktadır. Dolayısıyla su kaynaklarımızı zaman kaybetmeden enerji üretimine dâhil etmemiz gerekmektedir.

Gelişen ve değişen dünyada, gelişmiş ülkeler özellikle katma değeri yüksek alanlara yatırım yapmaktadır. Bu alanlardan birisi de enerjidir. Bilindiği üzere ülkelerin gelişmişlik seviyesi arttıkça enerji ihtiyacı da aritmetik olarak artmaktadır. Ülkemizin Asya ile Avrupa arasında enerji koridoru olma çabaları da bunun bir sonucudur. Gelişmenin yegâne lokomotifi bilim ve teknolojiye yatırım yaparak sanayileşmekten geçer, sanayileşmenin de en önemli girdisi enerjidir.

Devlet tarafından yapılmakta olan yatırımlara başlamadan önce yapılan keşifler her türlü ayrıntıyı içerecek şekilde hazırlanmalı ve devleti maddi yönden sıkıntıya sokacak yatırım esnasında keşif artışlarına yer verilmemelidir. Özel sektörün Yap-İşlet-Devret yöntemi ile yaptığ 1 yatırımlarda da hazine garantisi verilmemeli ve özel sektörün kar marjı ile devletin enerji üretimi nedeniyle oluşacak kazancı dengeli olmalıdır.

Hidroelektrik enerji üretimi amacıyla yapılacak baraj ve HES’lerin yer tespitlerinde, halkımızın sel ve heyelan riski taşıdığı bölgeler seçilmeli, bu bölgelerde yaşayan halk gerekirse kentsel dönüşüm yapılarak güvenli bölgelere taşınmalıdır. Barajlar, sel ve taşkınları kontrol altına alan yapılar olması nedeniyle vatandaşın can ve mal güvenliğini de korumaktadırlar. 


\section{Kaynakça}

Açıkalın, Şebnem (2007), "Yusufeli Barajı ve HES”, Su Dünyası, Devlet

Su İşleri Vakfı Yayınları, Ocak 2007, sayı 42,

Akdoğan, A. Argun (2006), "Latin Amerika'da Su Özelleştirmesi”, Su

Yönetimi, Edit: Tayfun Çınar ve Hülya K. Özdinç, Memleket Yayınlar1, 2006, Ankara, s.179-224.

Artvin Defterdarlığ 1 , http://www.artvindefterdarligi.gov.tr/?page=icerik\&-

file $=$ detay\&id=77, web adresinden 21.11.2015 tarihinde alınmıştır.

Bastın, Johan, 1999, "Sıra Suya Geliyor", Devrim Dergisi, 05 Nisan 2006

http://www.sendika.org/yazi.php?yazi_no=5671, web adresinden 25.10.2010 tarihinde alınmıştır.

Bilen, Özden (2003), Çevre Emperyalizmi ve Ilısu Barajı Örneği, ASAM (Avrasya Stratejik Araştırmalar Merkezi) Yayınları, Ankara,

DSİ (Devlet Su İşleri Genel Müdürlüğü), http://www.dsi.gov.tr/yusufeli_ projesi.pdf. web adresinden 19.04.2013 tarihinde alınmıştır.

DSİ (Devlet Su İşleri Genel Müdürlüğ̈̈), http://www.dsi.gov.tr/haberler/2015/01/28/yusufeli-baraj\%C4\%B1-ve-hes-projesi-i-n\%C5\%9Faat\%C4\%B1nda-\%C5\%9Falt-sahas\%C4\%B1-kaz\%C4\%B1lar\%C4\%B1-tamamland\%C4\%B1, web adresinden 21.11.2015 tarihinde alınmıştır.

DWP (Department of Water and Power), "The Colorado River: A Regional Solution", http://wsoweb.ladwp.com/Aqueduct/historyoflaa/ coloradoriver.htm, web adresinden 19.04.2013 tarihinde alınmıştır.

Çınar, Tayfun, 2006, “Türkiye'de İçmesuyu ve Kanalizasyon Hizmetleri”, Su Yönetimi, Tayfun Çınar, Hülya K. Özdinç(ed.), Memleket Yayınları, Ankara, Temmuz 2006, s.227-252.

Ege, A.Yavuz (2004), “Avrupa Birliği’nin Enerji Politikası ve Türkiye’nin Uyumu”, Avrupa Birliğinin Enerji Politikası ve Türkiye, Editörler: Yavuz Ege vd., Ulusal Politika Araştırmaları Vakfı, Dumat Ofset Matbaacılık, Mayıs 2004, 
Eroğlu, Veysel (2007), "Hizmette Yeni Bir Y1l”, Su Dünyasl, Devlet Su İşleri Vakfı Yayınları, Ocak 2007, sayı 42,

Kartal, Filiz (2006), "Suyun Metalaşması, Suya Erişim Hakkı ve Sosyal Adalet”, TMMOB Su Politikaları Kongresi 21-23 Mart 2006, TMMOB, Ankara, 2006, s.478-484.

Özen, Naci (2007), "Yusufeli ve Yusufeli Barajı", http://yusufeligercegi. blogspot.com/2007/01/yusufeli-ve-yusufeli-baraj.html. web adresinden 26.04.2010 tarihinde alınmıştır.

Özen, Naci (2009), Kusursuz Enerji Planı, G.M.Matbaacılık ve Tic.A.Ş., İstanbul, 2009

Özen Naci (2010), “Çoruh Enerji Planı, Büyük Ortadoğu Projesinin ülkemiz üzerinde ki son işlemidir”, http://artvin.biz/artvin-yazilar-323-coruh-enerji-plani-bop'un-ulkemiz-uzerindeki-son-islemidir.html. web adresinden 17.05.2010 tarihinde alınmıştır.

Sarıkız, Zeycan (2008), "Çoruh Nehri Hidroelektrik Gelişme Planı ve Yusufeli Baraji", http://alternatifsuforumu.org/index.php?option=com_ content\&task $=$ view\&id=41\&Itemid $=1 \&$ date $=2010-03-01$, Erişim tarihi 26.04.2010 tarihinde alınmıştır.

Sayıştay Raporu, 11.04.2002 tarihli,

Şimşek, Bedia Sanem (2006), "Su Sektöründe Reform Hareketleri-Yeni Politika Arayışları ve Rekabet Olanakları”, http://www.rekabet.gov. tr/index.php?Sayfa=tezdetay\&Id=79, web adresinden 25.03.2010 tarihinde alınmıştır.

Topçu, Ferhunde Hayırsever (2006), “Suda Dış Kredi:İzmit Örneği”, Su Yönetimi, Ed: Tayfun ÇINAR, Hülya K. ÖZDİNÇ. Memleket Yayınları, Ankara, Temmuz 2006, s.287-316.

U.S. Energy Information Administration, International Energy Outlook 2011, http://www.eia.gov/forecasts/ieo/pdf/0484\%282011\%29.pdf. web adresinden 24 Ekim 2012 tarihinde alınmıştır.

Yıkılmaz, Necla, (2003), Yeni Dünya Düzeni ve Çevre, İstanbul: Sosyal Araştırmalar Vakfı Yay. 
Yılmaz, Gaye (2008), "Su Sorununa Eleştirel Bir Yaklaşım: Üretimin Bir Faktörü Olarak Su”, Toplum ve Hekim Dergisi, TTB (Türk Tabipleri Birliği), Ocak-Şubat 2008, http://www.supolitik.org/elestirel_ bir_yaklasim.htm web adresinden 24.03.2010 tarihinde alınmıştır.

Yılmazer, İlyas (2007), "Yusufelinde Amaç Elektrik Üretmek Değil”, Yusufeli Dosyası Konferansı, Editörler:Neriman Özcan; Uğur Kutlukaya, Haziran 2007, İstanbul.

3996 Sayılı Bazı Yatırım ve Hizmetlerin Yap İşlet Devret Modeli Çerçevesinde Yaptırılması Hakkında Kanun, RG: 8.6.1994/ 21959

Yusufeli Barajı ve Hidroelektrik Santrali, http://www.limak.com.tr/sektorler/insaat/projeler/ barajlar/yusufeli-baraji-ve-hidroelektrik-santrali, web adresinden 21.11.2015 tarihinde alınmıştır.

Abstract: - Çoruh River and Yusufeli Dam: A Study of Social, Economic and Environmental Effects of a Dam - Çoruh River main stem and side branches are in the norteast of the country, long $390 \mathrm{~km}$ and 32 Hydroelectric Power Plant(HPP) were planned to build on it. When all the dams are proceeded, $8322 \mathrm{GWh}$ energy will be produced which is $\% 8$ of hydroelectric energy and \%34 total energy of the country. The costs of HPP's are shown lower than real when in theirs building process. International financial institutions like World Bank and IMF, by providing financial and technical support for the world's many privatizations in the region, is to encourage the efforts made in this regard. Necessary measures should be taken by the government, for investments made by private sector to bring additional cost to it. Hydropower potential should be put into production to be developed country. In this study we will emphasize the Black Sea area must be introduced where excess rainfall of energy production to meet our country's electricity needs and to reduce our country's dependence on other countries for energy, it is important to move the people to the safer areas who live with the risk of landslides and floods 
and react against the dams and power plants by people is driven by external forces.

Key words: Çoruh Valley, Çoruh River, Yusufeli Dam, Dam Policy, Slope HPP 

